\title{
An Alternative Techno Transfer through Modified Groundnut Stripper -A Case Study of KVK, Dharwad, Karnataka State, India
}

\author{
J.K. Sarojani ${ }^{{ }^{*}}$, J.S. Hilli ${ }^{2}$ and C.J. Kumar ${ }^{3}$ \\ ${ }^{1}$ Department of Food Science and Nutrition, College of Community Science, University of \\ Agriculture Sciences, Dharwad-580005, Karnataka, India \\ ${ }^{2}$ Department of Seed Science and Technology, ${ }^{3}$ Soyabean Scheme, University of Agricultural \\ Sciences, Dharwad-580005, Karnataka, India \\ *Corresponding author
}

A B S T R A C T

\begin{tabular}{|l|}
\hline Ke y w o r d s \\
Empowerment, Stripper, \\
$\begin{array}{l}\text { Drudgery, Groundnut, } \\
\text { KVK Dharwad } \\
\text { Intervention }\end{array}$ \\
\hline Article Info \\
\hline $\begin{array}{l}\text { Accepted: } \\
\text { 10 September } 2018 \\
\text { Available Online: } \\
\text { 10 October } 2018\end{array}$ \\
\hline
\end{tabular}

\section{Introduction}

Indian population comprises of 48.1 per cent women and 51.9 per cent men. Women constitute approximately 70 per cent of the agricultural labour force. In rural India, the percentage of women who depend on agriculture for their livelihood is as high as 84 . Women make up about 33 per cent of cultivators and about 47 per cent of agricultural labourers. These statistics do not account for work in livestock, fisheries and various other ancillary forms of food production in the country. (Krishna, 2006). They are actively involved in many of the field activities including harvesting and postharvest operations. Rural women's work ranges from crop production till consumption and women can be relieved of drudgery while attending the agricultural operation by use of improved technologies. Therefore, it becomes imperative to empower farm women with appropriate technology to reduce the drudgery, stress and enhance efficiency, productivity and satisfaction. Role of women in agriculture is as important as men, therefore women should 
educate themselves in agriculture. Harvesting is one of the most drudgery prone task with high energy and cost, thereby making it amenable to ergonomic interventions in terms of improved technologies (Viz., Modified Groundnut Stripper) to relieve women from high energy demands associated with drudgery to get clean produce.

Groundnut is an important leguminous oilseed crop grown in India. It occupies an area of 5.2 Million hectare with approximate productivity of $1180 \mathrm{~kg} / \mathrm{ha}$ (2008-09). It is grown in semiarid regions especially in the states of Gujarat, Andra Pradesh, Tamilnadu, Karnataka and Maharastra (Basu and Singh, 2004). Among the many fast growing cash crops groundnut is always sought after by small farmers. The crop can be grown even during dry season and can be harvested in 120-150 days. But the major hardship in growing this crop is harvesting and threshing. It is laborious and time consuming process. The fields need to be made wet on the previous day with scant irrigation so that soil becomes loose and plants along with pods can be pulled out easily from the soil. Once plucked, the pods need to be stripped from the plant. Stripping pods is a traditional practice done either manually or by beating bunches to the harrow blades. These methods are quite difficult and damage the hands and fingers and women suffer pain in the shoulder and back. There is no guarantee that all the pods can be removed from the plant. Manual stripping method requires about 160 human labours per ha. Hence, promotion of low cost improved techniques is necessary not only to reduce human labour but also to reduce cost (Govindraj and Mishra, 2011).

\section{Materials and Methods}

The study was undertaken with an objective to assess ergonomic cost of harvesting work specially stripping groundnut pods with existing and improved technologies and evaluate the cost involved and also to get the feedback on drudgery from the women labour. On farm testing was conducted by KVK, Saidapur farm, Dharwad in different villages on groundnut fields to study the performance and suitability of the existing stripper having "V" shape mesh with traditional methods i.e. manual stripping and beating plants on harrow blade. Later during Modified Ground nut stripper which facilitates to work by three labours simultaneously was modified fabricated, fine-tuned and tested over manual stripping and beating on harrow blade. The villages selected for study were from Dharwad district, Karnataka state of India viz., Marewad, Karadigudda, Yadawad, Agadi, Somapur and Mangalagatti. Feedback was taken from farmers and farm women labours $(n=60)$ and data collected on performance of modified ground nut stripper in the year 201314.

\section{Results and Discussion}

Results from Table 1 show that labour requirement as well as expenditure on labour was less in $\mathrm{TO}_{3}$, where Ground nut stripper was used when compared with Traditional methods viz., beating against harrow blade and manual stripping of groundnut. Expenditure on labour for stripping $100 \mathrm{q}$ was lowest viz., Rs. 12500 with use of stripper with $\mathrm{v}$ shape wire mesh when compared with beating against harrow blade Rs.15000 $=00$ and manual stripping of groundnut Rs. $21429=00$.About 71.43 per cent reduction in labour cost is seen when compared with manual stripping. However, feedback received from farmers/farm women revealed that the pods were stripped along with root for GPBD4 tested under summer condition which resulted in lesser market price for produce. Hence, modifications were made based on the farmers' and farm women opinion. Shape of blade was changed from ' $\mathrm{V}$ ' to a bar shape with a metallic sieve in the centre. A modified 
groundnut stripper length -2 feet, breadth-2 feet and height-16 inches The unit consists of a square frame of four vertical stands with a strip of expanded metal fixed on three sides and left vacant on one side. The shape of the stripping blade is converted from ' $\mathrm{V}$ ' shape mesh to a metallic cylindrical bar. Sieve is placed in slanting position in the centre so that stripped clean pods get collected on tadpal and mud, stone and small clods gets passed through sieve. This unit facilitates use by three women labours at a time.

The study conducted with KVK Dharwad modified ground nut stripper (Table 2) revealed that, the labour cost in stripping of 100 quintals of pods from the plant was highest in manual (Rs.18,750) with a consumption of 125 labours followed by beating the plant to harrow blade (Rs.15,000) with 100 labours and lowest in KVK, Dharwad modified stripper (rs.7500=00)with 50 labours. Nearly 50-60 per cent of labour cost can be saved through KVK, Dharwad modified stripper when compared to other two conventional methods. During labour shortage, KVK, Dharwad modified model plays a pivotal role in small farmers' sustainable Agriculture. Similarly in the study conducted by Adake et al., 2008 reported that the cost of groundnut stripping was appreciably reduced with stripper compared to conventional method.

Ghatge et al., 2014 also reported that average stripping rate of pedal operated stripping machine was six times more than traditional hand stripping and there was no damage to the pods. Rajasekar et al., 2017 reported that with the newly designed Ground nut thresher, $48 \mathrm{~kg}$ of ground nut can be collected per hour (336 $\mathrm{kg}$ /day with three litres Of fuel and oil).When compared to manual cost it is less by Rs. 940 and economical.

Sixty farmers / farm women were randomly selected to assess the performance of modified ground nut stripper. The results of the study from Table 3 revealed that majority of the subjects in the study were illiterate (46.67\%), followed by subjects up to $7^{\text {th }}$ standard $(18.33 \%)$ then by $10^{\text {th }}$ standard. In the present study it was found that majority of farmers were in the category small/marginal farmers (86.67 per cent) followed by medium (10 per cent) and then by large farmers (3.33 per cent). About 15 per cent of respondents owned Tractor.

Table.1 Performance of Groundnut stripper with 'V' shape wire mesh

\begin{tabular}{|l|c|c|c|c|}
\hline Technology Assessed & $\begin{array}{c}\text { A verage Qty of } \\
\text { groundnut } \\
\text { stripped/ day/ } \\
\text { farmwoman(q) }\end{array}$ & $\begin{array}{c}\text { Expenditure } \\
\text { on labour for } \\
\text { stripping 1 q } \\
\text { (Rs) }\end{array}$ & $\begin{array}{c}\text { Labours for } \\
\text { stripping 1q }\end{array}$ & $\begin{array}{c}\text { Expenditure } \\
\text { on labour for } \\
\text { stripping } \\
100 \text { q (Rs) }\end{array}$ \\
\hline $\begin{array}{l}\text { Technology option 1: } \\
\text { Beating against } \\
\text { harrow blade }\end{array}$ & 1.00 & $150=00$ & 1 & $15000=00$ \\
\hline $\begin{array}{l}\text { Technology option 2: } \\
\text { Manual stripping of } \\
\text { groundnut }\end{array}$ & 0.70 & $214=29$ & 1.43 & $21429=00$ \\
\hline $\begin{array}{l}\text { Technology option 3: } \\
\text { Use of groundnut } \\
\text { stripper }\end{array}$ & 1.20 & $\mathbf{1 2 5 = 0 0}$ & 0.83 & $\mathbf{1 2 5 0 0 = 0 0}$ \\
\hline
\end{tabular}


Table.2 Performance of the KVK Dharwad modified Ground nut stripper

\begin{tabular}{|l|l|c|c|c|}
\hline Technology assessed & $\begin{array}{l}\text { A verage } \\
\text { quantity } \\
\text { stripped } \\
\text { (q/day/farm } \\
\text { woman) }\end{array}$ & $\begin{array}{l}\text { Expenditure } \\
\text { on labour for } \\
\text { stripping } 1 \text { q } \\
\text { (Rs) }\end{array}$ & $\begin{array}{l}\text { Labours } \\
\text { stripping } \\
100 q(\text { formbers) }\end{array}$ & $\begin{array}{l}\text { Expenditure } \\
\text { on labour } \\
\text { for } \\
\text { stripping } \\
100 \text { q (Rs) }\end{array}$ \\
\hline $\begin{array}{l}\text { Beating the plant against } \\
\text { harrow blade }\end{array}$ & 1.0 & $150=00$ & 100 & $15,000=00$ \\
\hline $\begin{array}{l}\text { Manual stripping of } \\
\text { ground nut }\end{array}$ & 0.8 & $187=50$ & 125 & $18,750=00$ \\
\hline $\begin{array}{l}\text { KVK Dharwad modified } \\
\text { ground nut stripper }\end{array}$ & 2.0 & $75=00$ & 50 & $7,500=00$ \\
\hline
\end{tabular}

Table.3 Demographic Profile of subjects selected for the study $(n=60)$

\begin{tabular}{|l|l|l|}
\hline Particulars & Number (n) & Percentage (\%) \\
\hline Men & 30 & 50 \\
\hline Women & 30 & 50 \\
\hline Education status & & \\
\hline Illiterate & 28 & 46.67 \\
\hline Upto 5 $^{\text {th }}$ & 06 & 10.00 \\
\hline Upto $7^{\text {th }}$ & 11 & 18.33 \\
\hline Upto 10 & 08 & 13.33 \\
\hline Pre University & 05 & 08.33 \\
\hline Under Graduate & 02 & 03.33 \\
\hline Number who own tractor & 09 & 15.00 \\
\hline Land Holdings & 52 & 86.67 \\
\hline $\begin{array}{l}\text { Small/ Marginal Farmers (Less than } \\
\text { or equal to 2 ha) }\end{array}$ & 52 & 10.00 \\
\hline $\begin{array}{l}\text { Medium Farmers(Greater than 2 ha } \\
\text { and less than or equal to 5 ha) }\end{array}$ & 06 & 03.33 \\
\hline \begin{tabular}{l} 
Large Farmers(More than 5 ha) \\
\hline
\end{tabular} & 02 & \\
\hline
\end{tabular}

Table.4 Opinion of respondents regarding KVK Dharwad modified groundnut stripper ( $\mathrm{n}=60)$

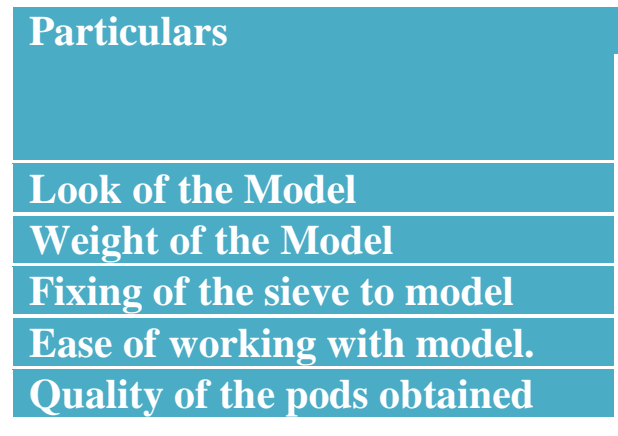

\begin{tabular}{|l|l|l|}
\hline $\begin{array}{l}\text { Acceptability } \\
\text { Highly } \\
\text { Acceptable n (\%) }\end{array}$ & $\begin{array}{l}\text { Moderately } \\
\text { Acceptable n }(\%)\end{array}$ & $\begin{array}{l}\text { Not acceptable } \\
\mathrm{n}(\%)\end{array}$ \\
\hline $52(86.67 \%)$ & $08(13.33 \%)$ & 00 \\
\hline $51(85.00 \%)$ & $08(13.33 \%)$ & $01(01.67 \%)$ \\
\hline $60(100 \%)$ & 00 & 00 \\
\hline $56(93.33 \%)$ & $04(6.67 \%)$ & 00 \\
\hline $58(96.67 \%)$ & $02(3.33 \%)$ & 00 \\
\hline
\end{tabular}



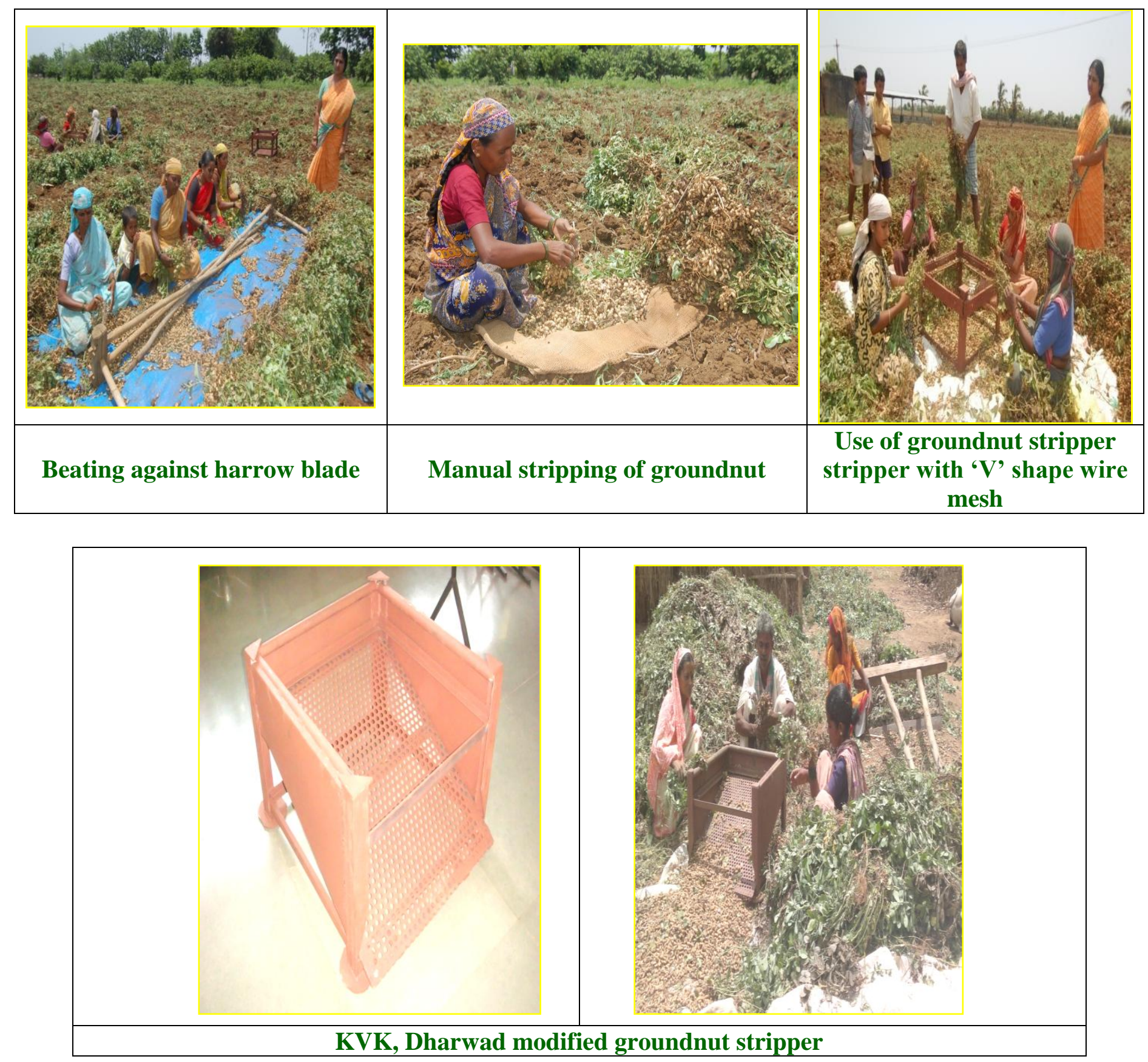

Table 4 shows the acceptability of KVK Dharwad modified sripper, model. More than 85 per cent of farmers /farm women rated the model with respect to efficiency and weight as highly acceptable. Stripping with Stripper was highly acceptable with respect to ease by 93.33 per cent and moderately acceptable by 6.67 per cent. They did not suffer from tiredness or pain in shoulders. In the manual method of stripping women suffer from injuries on palms and pain in shoulders due to continuous work. Oberoi and Singh (2001) stated that stripping of groundnut was identified as one of the most drudgery prone tasks performed by women labour. Maximum drudgery prone activities like weeding, 
cutting, uprooting, transplanting, harvesting, threshing and stripping are performed by women labour. Manual stripping of groundnut is laborious and women suffer from pain in shoulder and back Quality of the pods obtained was highly acceptable by 96.67 per cent and moderately acceptable by 3.33 per cent.

The model developed by KVK, Dharwad is user friendly, convenient, low cost and useful during the labour scarcity and the pods stripped were clean without any roots, mud, stone and Plant debris. A woman labour could be able to strip 2 quintals of groundnut pods per day and the stripper facilitates three woman labours at a time. Nearly 50-60 percent of labour cost can be saved through KVK Dharwad modified stripper when compared to manual and beating against harrow. During labour shortage, modified KVK Dharwad model plays a pivotal role in small farmers' sustainable Agriculture. Hence, it may be concluded that modified stripper has significant contribution in reducing the drudgery and increasing the output.

\section{Application of research}

Applied to agriculture laborers and cultivators for women to save the workload.

\section{Acknowledgement / Funding}

Author thankful to University of Agricultural Sciences, Dharwad Dr. Jitendrakumar S. Hilli, Worked as Programme Coordinator, Mr.
Kumar C. J., Worked as Technical Assistant, University of Agricultural Sciences, Dharwad.

\section{References}

Adake R V, (2008) Srinivas T, Mayande M and Reddy B S, Indian Journal of Dry land Agriculture and Research Development.Vol23

Andhale A S, Wajahat S, Lawhale P, Mendhe $\mathrm{K}$ and Tufail M S (2017) Design and Development of Groundnut Pod Separating Machine. International Journal of Latest Engg. Management Research. 2(04); 38-40.

Basu M S and Singh N B (2004), Groundnut Research in India, National Research Centre for Groundnut (NRCG) Junaghadh.

Ghatge J S Bandgar P S and Mehetre S A (2014) Development and Evaluation of pedal operated ground nut pod stripping machine. Internat. J. Agri. Engg., 7(1) April 2014; 217-220

Govindraj, G, and A P Mishra (2011), Agricultural Economics Research Review, Vol-24(Conference No), pp. 423-428. Directorate of Groundnut Research (ICAR), Junarghadh, Gujarath.

Oberoi $\mathrm{K}$ and Singh $\mathrm{O} \quad \mathrm{P}$, All India coordinated Research project in Home Science: Annual Report, ICAR, New Delhi, 2001.

Rao E and Krishna (2006), Role of women in Agriculture: A microbial study, Journal of Global Economy vol. 12.

\section{How to cite this article:}

Sarojani, J.K., J.S. Hilli and Kumar, C.J. 2018. An Alternative Techno Transfer through Modified Groundnut Stripper -A Case Study of KVK, Dharwad, Karnataka State, India. Int.J.Curr.Microbiol.App.Sci. 7(10): 1132-1137. doi: https://doi.org/10.20546/ijcmas.2018.710.125 